\title{
Assessment of causes leading to an insufficient water supply in Tegucigalpa, Honduras
}

\author{
Z. Coello-Balthasar ${ }^{1,2,3}$, P. Phumpiu ${ }^{1}$, B. Balfors ${ }^{1}$ \\ \& J. E. Gustafsson ${ }^{1}$ \\ ${ }^{I}$ Department of Land and Water Resources Engineering, \\ Royal Institute of Technology, Sweden \\ ${ }^{2}$ School of Geographical and Earth Sciences, \\ University of Glasgow, UK \\ ${ }^{3}$ Facultad de Ingeniería, Universidad Nacional Autónoma de Honduras, \\ Honduras
}

\begin{abstract}
Tegucigalpa, the capital of Honduras with nearly one million inhabitants has been experiencing severe water shortage for the past decades resulting in intermittent water supply, ranging in some cases from 18 to 24 hours per week, and limited access to piped water in the topographically higher regions of the city. For the past 50 years the responsibility over Tegucigalpa's water supply lay with the National Autonomous Aqueduct and Drainage Service (SANAA). Through interviews with persons from various organizations active in Tegucigalpa's water sector, problems that contributed to the ongoing water shortage were analyzed. The results suggest that the performance of SANAA has largely been compromised through the interference with and dependence on other central governmental agencies and local authorities. Municipalisation is advocated as a new opportunity for the water supply of Tegucigalpa, if the Municipality, as the new agent, is able to provide an institutional environment for planning execution, project continuity, and qualification-based recruitment. Keywords: water supply, municipalisation, Tegucigalpa, Honduras.
\end{abstract}

\section{Introduction}

Insufficient water supply is a serious problem affecting the environment, people and their activities on different levels ranging from managing crop production, 
upholding hygienic standards to the availability of clean drinking water. A country facing this problem is Honduras, where the average precipitation decreases from coastal regions towards the interior due to its mountainous terrain. Tegucigalpa, the capital and with more than one million inhabitants [1] is the largest city of Honduras, and located in the interior mountainous terrain. The metropolitan area of Tegucigalpa is composed of two cities, Tegucigalpa and Comayagüela, which are separated by the Choluteca River. In the following paper, Tegucigalpa will refer to the metropolitan area that comprises both cities.

The combination of a mountainous terrain and pronounced climatic seasonality represents a challenge for the water supply of Tegucigalpa which is served by two main water reservoirs: Concepción with a storage capacity of 33 millions of cubic meters $\left(\mathrm{Mm}^{3}\right)$ and Los Laureles with a capacity of $12 \mathrm{Mm}^{3}$ [2]. Additional minor water resources are represented by springs (Picacho), rivers, and wells, all of which partially dry up during the dry season. However, these combined sources of drinking water are insufficient to meet the needs of Tegucigalpa's population and have led to a permanent water shortage with only $52 \%$ of the required drinking water currently available during the dry season in Tegucigalpa [3].

As far back as the 1980's SANAA, which is the agency in charge of operating the water distribution in Tegucigalpa since 1961, introduced an intermittent water supply in order to cope with the permanent water shortage during the dry season [4]. Currently the population receives water for 4 to 12 hours per day during the rainy season and only every second or third day [5] for 6 to 8 hours during the dry season [6].

It is thus clear that water shortage in Tegucigalpa is a systematic and chronic problem that cannot be easily reduced to a single factor. The extent of this crisis raises questions about the contributing factors and the approaches used to address them. As the authority in charge of the water sector throughout the water shortage SANAA has not found the means to improve the supply of drinking water to full coverage.

Thus the objective of this paper is to investigate the factors that hinder a comprehensive water supply management of Tegucigalpa.

\section{Methodology}

A qualitative research approach was used because there is a need to explore, describe and explain a problem [7]. Primary data was collected through focus interviews with 17 people performed from April $12^{\text {th }}$ to May $9^{\text {th }} 2010$. Nine of the interviewees have managerial positions in different units of SANAA. These interviewees were selected using the snowball sampling technique, starting with the sub manager of SANAA. The snow ball sampling technique consists of each interviewee proposing additional people with the required background for these interviews [8]. Additional interviews were performed with two people in charge of water treatment plants and reservoirs, two SANAA trade union leaders (SITRASANAAYS), and one person each from the National Water and Sanitation Council (CONASA), the Regulatory Entity for the Drinking Water 
and Sanitation Sector (ERSAPS), and AMITIGRA (a NGO working for the environmental protection of the La Tigra national park, the source area for the Picacho water).

The points brought up by the interviews were later verified through studies of relevant documents.

\section{Historic background}

On the $26^{\text {th }}$ of April 1961, SANAA was created as the authority for the development and operation of the water supply and sewage systems for Honduras. By then SANAA realized that Tegucigalpa needed a reservoir [9] to guarantee water supply for the 164,941 inhabitants [10]. In May of the same year the construction of a new water reservoir in the Guacerique River was proposed as the best solution and in 1972 SANAA decided to build the reservoir. However, the project faced financial difficulties and it never came to fruition thus leaving Tegucigalpa with an unsatisfied water demand [9].

In 1973, 12 years after the Guacerique reservoir had been proposed for first time, the situation was becoming so critical that the "Emergency Plan Los Laureles" was initiated for the construction of a water reservoir for Tegucigalpa. The resulting reservoir, Los Laureles, was finished in 1976 with financial support from the Central American Bank of Economic Integration (BCIE) [2]. The reservoir was built downstream of what would have been Guacerique and with a smaller storage capacity than the original plans from 1961. This diminished capacity together with an increased population meant that soon after its finalization Los Laureles was insufficient to satisfy the water demand of the 305,387 inhabitants [10]. As a result of the continuing water shortage SANAA introduced an intermittent water supply during the 1980's [4].

It was not until 1991, when the deficit of water had reached $37 \%$ during the dry season [11] and the population had increased to more than 576,661 [12], that an additional source of water was incorporated to supply Tegucigalpa. This new reservoir, Concepcion, was financed by Italy and although supposed to cover the water demand until 2004 [13], SANAA was forced to re-introduce an intermittent water supply by 1998 [11].

Since the construction of Concepción, no considerable sources of water have been added to Tegucigalpa's water supply while the population has almost doubled and was close to one million in 2007. Groundwater has been added to the water supply, but only in small quantities [14]. Concepción reservoir now receives additional water from the Ojojona River and floodgates were built above the spillway increasing the storage capacity of the reservoir by $3.0 \mathrm{Mm}^{3}$ [15]. In Los Laureles, a $3.5 \mathrm{~m}$ high inflatable curtain was incorporated in 2002 to increase water storage by $3.5 \mathrm{Mm}^{3}$. More water has been derived to Picacho and in 2010 the capacity of water treatment plants was increased by $200 \mathrm{l} / \mathrm{s}$. Nevertheless, the storage capacity of Los Laureles is decreasing by $2 \%$ annually as the reservoir is silting up [16]. The inflatable curtain, which is about to reach the end of its service, was not operated in 2010 [17]. A new project, an update of the previously proposed Guacerique, now called Guacerique II, is a priority to 
the SANAA management as a solution for the continuing water crisis in Tegucigalpa.

\section{Results of interviews}

The historical analysis reveals a pattern of last minute measures to cope with a growing crisis of the water supply in Tegucigalpa. This is further confirmed by the performed interviews. In the course of the interviews 13 distinct problems were independently identified by the interviewees (Table 1). The following presentation is based on the opinions of the interviewees.

Rainfall Uncertainty - The uncertainty over the extent of the dry season or if the amount of rain during the rainy season will be sufficient to fill up the reservoirs represents a challenge for SANAA. In the current situation, where an intermittent water supply is even in practice when the reservoirs are at full capacity, an extended dry season results in a decrease of the hours of water supply.

Increasing Water Demand - While the population continues to grow, water resources remained largely constant since the construction of Concepción in 1991. As one interviewee expressed, "It is a redistribution of what we have, that is all what we can do".

Settlements in High Areas - The city is largely growing in an unorganized and unplanned way and increasingly occupying more mountainous areas. Areas above an elevation of 1,150 meters above sea level represent a problem for SANAA as piped water would need to be pumped for which no funding is available.

Deterioration of Sources of Water - Catchments with potential to produce water have been deteriorated by deforestation which has increased erosion and also because of the presence of settlements. Settlements are a source of pollution due to improper disposal of waste water. Furthermore, in case of the construction of a dam, the inhabitants settled in the flooding area will demand compensatory payments, therefore increasing the costs of the project.

Competing Needs - Apart from drinking water, water is needed for agriculture, industry or for other municipalities within the same catchment. Water used for these competing needs will not necessarily be available for drinking water.

Lack of Cooperation from the Municipality- Interviewees mentioned a conflicting relationship between SANAA and the municipality, for example, when the municipality authorizes settlements in high or in protected areas of the city. Also, SANAA has to invest resources creating and updating a database of the new constructions in the city, information handled by the Municipality. "The municipality and SANAA have traditionally been antagonists, and there has been little cooperation" expressed one of the interviewees.

Subsidized Tariff- The price of the water service is so low that SANAA is not able to expand or maintain its distribution network or to incorporate and fund new sources of water to the system. Water prices are controlled by the National 
Table 1: $\quad$ Problems highlighted during the interviews.

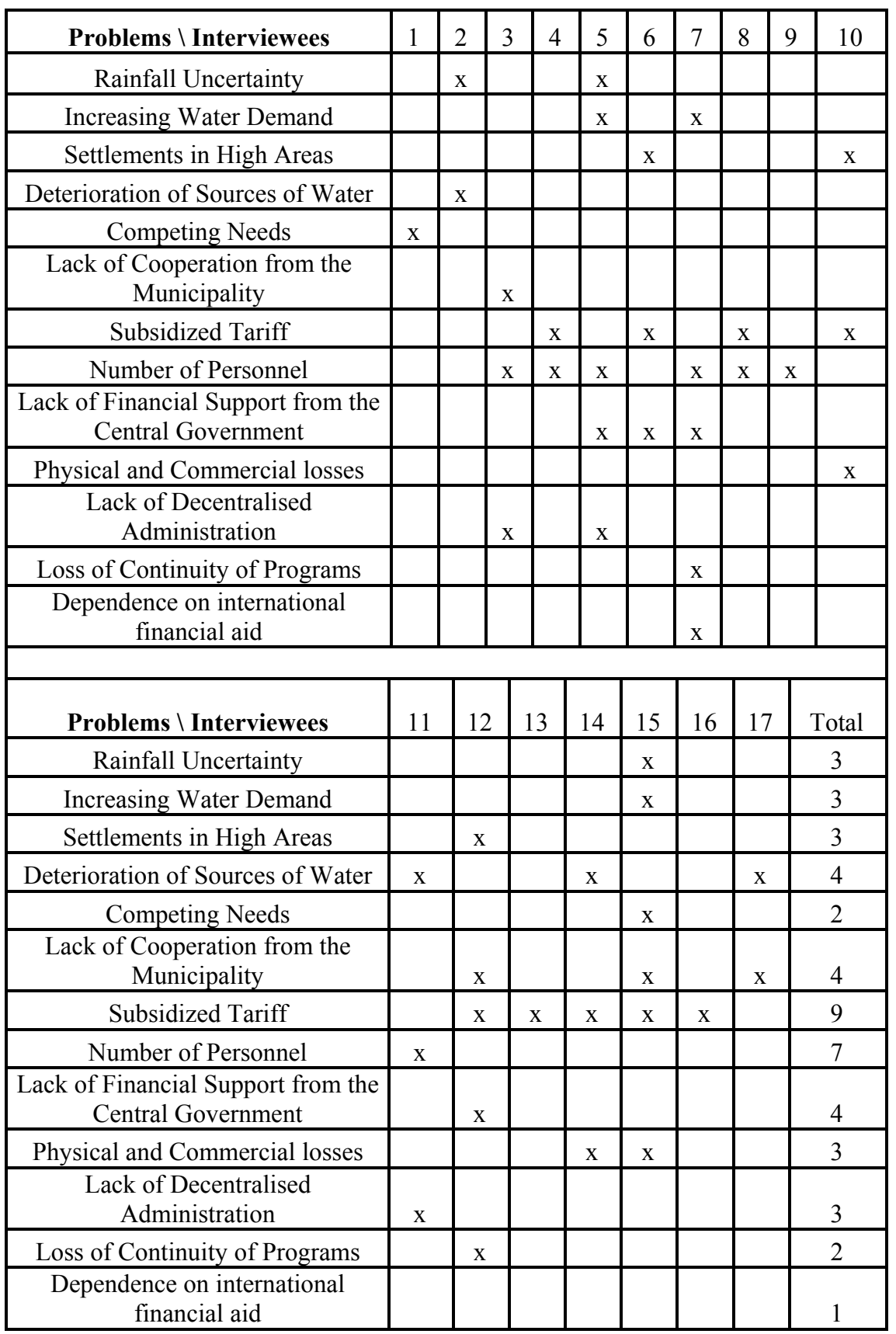


Government and increases are only approved when SANAA is unable to pay the salaries of its employees.

Number of Personnel - SANAA employs more personnel than needed (14 employees per 1000 connections in Tegucigalpa; average in other cities in Honduras is 4) [18]. One of the main reasons for this situation is that with every change of government, new employees are recruited for political reasons and the trade union (SITRASANAAYS) protects already recruited employees from being fired. This excess of personnel is draining financial resources and compromises overall efficiency.

Lack of Financial Support from the Central Government - SANAA is directly financed through the water tariff and benefits from a variety of subsidies through the Central Government [19]. But, because the price for water is controlled by the national government, SANAA is not financially independent. SANAA's current financial situation does not allow for necessary maintenance of the existing water infrastructure. Financial support from the national government had only been granted in the case of the unusually long dry season of 2010 .

Physical and Commercial losses - Unquantifiable amounts of water are lost in the distribution network either by theft or leakages and create a financial burden to SANAA and substantially compromise the overall water distribution.

Lack of Decentralization - On a national level SANAA is divided into seven regional branches. Income from the SANAA sub-branch for Tegucigalpa is used to subsidize smaller non-profitable services in other municipalities.

Loss of Continuity of Programs - With every new national government the president of Honduras will assign a new senior management to SANAA. The frequent changes to the senior management hamper the development of a sustainable long-term strategy for existing challenges in the water sector.

Dependence on international financial aid - Projects targeting the improvement and maintenance of the water infrastructure depend on finding international funding.

The dominant trend of the interviews was to explain the deficient water supply service with the financial limitations of SANAA, particularly the low price of the water service (18.8\%) and the high number of SANAA's employees $(14.6 \%)$. Figure 1 depicts all the mentioned problems that hinder a comprehensive management of the water supply.

\section{Discussion}

The opinions of the interviewees are further underlined by the following review of relevant documents as the base for the discussion.

\subsection{Rainfall uncertainty}

Tegucigalpa receives about $1,100 \mathrm{~mm}$ of precipitation per year, but this is distributed unevenly over the year with as low as $4 \mathrm{~mm}$ during months of the dry season (November - April) and $163 \mathrm{~mm}$ during months of the rainy season (May - October) [20]. Ideally, existing reservoirs should fill up during the rainy season 


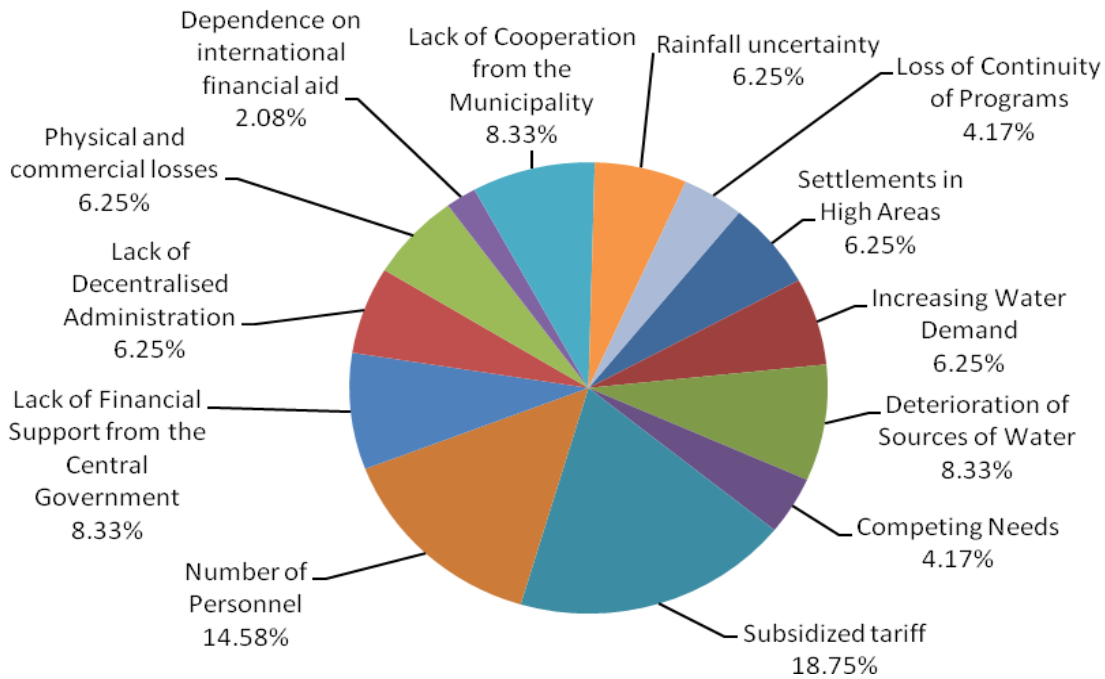

Figure 1: Relative frequency of the identified problems contributing to the sustained water shortage of Tegucigalpa.

and last throughout the dry season. Delays in the onset of the rainy season increase the stress on water resources use.

The catchment areas with water supply potential for Tegucigalpa have a capacity to produce $180 \mathrm{Mm}^{3}$ per year of surface water [11]. Water storage during the rainy season is the most effective way to assure water availability during the dry season. It is evident that if SANAA has opted to use an intermittent water supply, then the storage capacity is at this moment considered insufficient to provide an efficient supply to Tegucigalpa. There is an urgent need to incorporate a new reservoir to the water supply of Tegucigalpa.

\subsection{Impacts of uncontrolled population growth for planning and water supply}

Tegucigalpa is growing in an unorganised and unplanned way occupying the high mountainous areas and the protected areas with water supply potential. The population growth means an increase of the demand for water, but the amount of the supply has remained constant.

Related to population growth is the area towards which the new urban spaces are expanding and its consequences for SANAA. Despite the fact that Tegucigalpa is located in an area which is not favourable for urban expansion (i.e. surrounded by mountains, a highly irregular topography, prone to landslides, and few valleys [4] ), the urban area has more than tripled in size over the past 25 years [21]. The growth has followed the trend of informal illegal settlements growing at the edges of the urban core, in areas with steep slopes, and irregular land tenure [22]. Although the Municipality has the responsibility to control these settlements, they lack the power to do so. This has led to the situation that 
$60 \%$ of the land in Tegucigalpa has no clear ownership, $46 \%$ of all current residential properties were obtained through illegal land invasion, $8 \%$ of the settlements are in areas higher than the legal limit of 1,150 meters and urban expansion has already started to penetrate protected areas with water supply potential, such as the Guacerique River watershed [21]. Piped water will not be provided to these settlement unless legal land tenure can be demonstrated [23].

Protection of catchments, according to the General Law of the Environment of 1993, is a shared responsibility among different governmental agencies called National Network of Hydrographical Catchments. Even though SANAA forms part of the Network, it has been powerless to prevent authorized housing constructions in the protected sub-catchments, such as La Tigra and Guacerique.

For example, the Guacerique catchment was declared a protected forestry zone in 1973. In 1986 this status was temporarily removed and the construction of a low-income housing project known as Ciudad Mateo on the hill slopes fringing Los Laureles Reservoir was approved by the National Congress [16]. The project was stopped when 2,300 houses had already been built. The houses have remained uninhabited ever since and now are the focus of controversy over whether they should be occupied or demolished because of the risk of pollution to Los Laureles Reservoir [24].

Declaring the catchment areas with water supply potential protected has created a problem to the habitants of those areas. A consultancy work performed by the Italian Engineering Society [25] narrates how the population who depended on the forestry industry had to shift to agricultural practices. Excessive amounts of fertilizers and pesticides have allowed that land suitable for forestry is now used intensively for crop production leading to soil degradation and water pollution, especially to Los Laureles reservoir in the Guacerique catchment.

Thus Tegucigalpa lacks a coordinated and comprehensive water planning capacity.

\subsection{Conflict of legal and planning interests}

When it comes to new legal construction or urbanization, the owner must obtain the authorization to start building from the Municipality and from SANAA. The Municipality, as well as SANAA face the same problem of owners failing to comply and legalise the constructions [26, 27]. The Municipality as well as SANAA should apply fines to punish evaders.

This rivalry could also be explained from the historic perspective, given by the Reform of the Water Sector. In the case of Tegucigalpa, several attempts have taken place to reform water administration by moving the authority from the national to the municipal level. Beyond the particular problems of water availability in Tegucigalpa, the process of municipalisation started in 1990 when the National Congress of Honduras passed the Municipal Law bill. The devolution of power from the national to municipal levels was aimed at improving the overall living standards as different municipalities faced different problems that needed different solutions. As part of this law, municipalities became responsible for constructing, administering and maintaining the networks of piped water and sewage, functions that were the responsibility of SANAA. 
Therefore, the Municipal Law resulted in a duplication of functions. In 1994, when the process of municipalisation of the water networks had already started, the director of SANAA argued that SANAA could become profitable and functional by reducing its personnel and creating regional centres [28]. By 1996, the lack of a solid national alliance among the different actors (municipalities, donor governments, users, and politicians) in favour of the reform led to its failure and only a few networks were municipalised [19].

Another attempt to reform the water services took place in 2003 when the Water Supply and Sanitation (WSS) Sector Framework Law was approved. The WSS Sector Framework Law created CONASA and ERSAPS. CONASA is responsible for establishing policies, developing strategies and investment programs, as well as coordinating the activities for improving the water and sanitation sector at a national level. ERSAPS role is to regulate and control the providers of the sewage and water services at a national level and the regulation of water tariffs according to their criteria, methods and procedures.

The WSS Sector Framework Law reinforced that the responsibility for providing the service of drinking water and sewage falls to the municipalities. Unlike the law of 1990, this law specifically stated that SANAA should transfer gradually, free of any debts, all systems and all their assets to the municipalities within five years.

As part of the reform, the Framework Law also demands that SANAA pays compensatory work benefits to all of its employees who will be dismissed from their duties. The financial resources to cover these compensation costs were supposed to be made available by the President of Honduras. By 2008 the funding of these costs was still unresolved and a modification to the WSS Sector Framework Law was issued identifying the need to find a way to finance the compensatory work benefits, as well as strategies for the technical-administrative training of the new providers of the service. An extension of five more years was granted to finalize the municipalisation of the water sector in Tegucigalpa and to pay the work benefits of the employees which add up to more than 65 million US\$ [29].

\subsection{Financial limitations}

According to the interviewees, SANAA has not been able to build a new reservoir because of financial constrictions including the little financial support the Central Government has offered on this matter. The origin of the financial problems of SANAA's limitations varied among the different interviewees. An important reason is SANAA's inability to change water prices, which has led to a situation where running costs are higher than income.

Researchers have addressed the issue of the low price of the water service in Tegucigalpa and have recognized that SANAA has no opportunity to either expand or maintain the distribution network [16, 19, 30]. Strand [30] analyzed the following consequences of the low prices of water: (a) SANAA is not able to cover even its variable costs through water tariffs; (b) low prices reduce SANAA's incentive to extend coverage to new consumer groups; (c) SANAA has low incentives to collect water bills; (d) low prices discourage maintenance, 
improvements in the distribution system; (e) low prices mean little incentive for expanding existing water sources or opening up new ones; (f) income distribution.

\subsection{Influence of the Central Government in the water sector}

Interviewees pointed out a close interrelation between the financial limitations and the influence of the Central Government due to the power the government has on establishing the price of water [11].

Other aspects of the influence of the Central Government are indirect. For example, a newly elected president will reward those who supported him during the election campaign by offering them administrative offices, including the position of the manager of SANAA. This type of recruiting system is known as the spoils system [31]. The spoils system has led to (i) a loss in continuity of the running and planned programs, (ii) the recruiting of the job seekers who worked during the elections for the victorious party in positions that were not vacant, therefore increasing the payroll and weakening SANAA financially [28], and (iii) the lack a sense of identity between employees and the company who realize their job would be threatened in the next electoral period.

\section{Conclusion}

This assessment has shown that a comprehensive management of water supply in Tegucigalpa does not exist. The public water company SANAA lacks financial resources to cope with growing water supply demand. Also the uncontrolled growth and development of Tegucigalpa puts SANAA in a difficult situation. This is not likely to change before the overall planning situation of Tegucigalpa is improved and the so called spoils system is abandoned.

\section{References}

[1] INE, Trigésima Quinta Encuesta Permanente de Hogares Septiembre 2007 in EPHPM - XXXV. 2007, Instituto Nacional de Estadística de Honduras: Honduras.

[2] OIRSA, Descripción de Embalses de Honduras, OIRSA, Editor. 2007, Organismo Internacional Regional de Sanidad Agropecuaria.

[3] Ortiz, P., Programa Plan Maestro de Abastecimineto de Agua para Tegucigalpa: Corto, Mediano, y Largo Plazo. 2005, Servicio Nacional de Acueductos y Alcantarillado (SANAA): Tegucigalpa.

[4] Caballero, E., Gestion Urbana y Participación Popular en la Ciudad de Tegucigalpa en la Década de los 80, ed. M. CSUCA, UNO+UNO Consultores. 1992, Tegucigalpa: Ediciones Zas.

[5] Andino, J.C., Informe de la Situacion del Servicio de Agua de la Ciudad Capital, in Foro Agua Para la Capital. 2009, CICH: Tegucigalpa.

[6] SANAA, Redistribucion de Horarios de Servicio de Agua Potable, in Diario La Tribuna. 2010: Tegucigalpa. 
[7] Yin, R., Case Study Research: Design and Methods. Fourth Edition ed. 2009, California: SAGE Publications.

[8] Patton, M., Qualitative Research \& Evaluation Methods. Third Edition ed. 2002, California: Sage Publications, Inc.

[9] SANAA, Informe Final Primera Etapa para Tegucigalpa, D.C. 1983, Lahmeyer International GMBH, CONASH Consultores Asociados de Honduras: Tegucigalpa.

[10] DGEC, Primer Centenario de la Dirección General de Estadística y Censos Junio 1880-1980. 1980, Direccion General de Estadística y Censos: Tegucigalpa.

[11] PCI, Estudio del Sistema de Abastecimiento de Agua para el Area Urbana de Tegucigalpa en la Republica de Honduras, Informe Final, Informe Principal. 2001, Pacific Consultants International (PCI), Agencia de Cooperacion Internacional de Japon (JICA), Secretaría Técnica de Cooperación Internacional (SETCO), Servicio Autonomo Nacional de Acueductos y Alcantarrillados (SANAA). p. 189.

[12] DGEC, Censo Nacional de Población y Vivienda 1988, in Población Total y N'umero de Viviendas por Departamento y Municipio, Resultados Definitivos. 1989, Dirección General de Estadísticas y Censos: Tegucigalpa.

[13] SANAA, Actualizacion del Plan Maestro. 1990, BCEOM-CASTALIA.

[14] Berrios, F., Abandono de Proyecto Epas Agudiza Crisis de Agua, in El Heraldo. 2009: Tegucigalpa.

[15] JICA, Informe del Estudio Preliminar sobre el Proyecto de Abastecimiento de Agua para el Area Urbana de Tegucigalpa. 2006, Agencia de Cooperación Internacional del Japón.

[16] Lee, M., Multiple Resource Needs and Multiple Conflicts in Urban Watersheds in Developing Countries: The Case Study of the Guacerique Watershed, Tegucigalpa, Honduras, in Integrated Management of Surface and Groundwater. UCOWR Annual Meeting. 1996: San Antonio, Texas.

[17] Morales, A. and N. Garcia, Ahora Desperdician el Agua, in La Prensa. 2010: San Pedro Sula.

[18] ERSAPS, Agua y Saneamiento en Honduras Indicadores. Edición 2009. 2009, ERSAPS: Tegucigalpa.

[19] Walker, I., et al., Esfuerzos de Reforma y Equilibrio de Bajo Nivel en Sector de Agua de Honduras, in Agua Perdida: Compromisos Institucionales para el Suministro de Servicios Públicos Sanitarios, P. Spiller, Savendof, W., , Editor. 2000, Inter-American Development Bank: Wasington, D.C. p. 41-99.

[20] Westerberg, I., et al., Precipitation Data in a Mountainous Catchment in Honduras: Quality Assessment and Spatiotemporal Characteristic. Theoretical and Applied Climatology, 2010. 101(3 ): p. 381-396.

[21] Angel, S., et al., Rapid Urbanization in Tegucigalpa, Honduras. Preparing for Doubling of the City's Population in the Next Twenty-five Years, P. University, Editor. 2004: New Jersey. 
38 Water Resources Management VI

[22] Pearce-Oroz, G., Causes and Consequences of Rapid Urban Spatial Segregation: The New Towns of Tegucigalpa, in Desegregating the city: Ghettos, Enclaves, and Inequality, D. Varady, Editor. 2005, State University of New York.

[23] Ortiz, A., Latin America \& the Caribbean - Urban services delivery and the poor : the case of three Central American cities. 2002, World Bank. p. 132.

[24] Calix, G., SANAA se opone rotundamente a que se habilite Ciudad Mateo, in El Heraldo. 2009: Tegucigalpa.

[25] SANAA, Estudio de Rehabilitación Ambiental en Cuatro Subcuencas Hidrográficas del Sistema de Abastecimiento de Agua Potable para Tegucigalpa. 2005, ESA Consultores, C. Lotti \& Associati: Tegucigalpa.

[26] Medina, A., Suman 470 las Obras Paralizadas en la Capital, in El Heraldo. 2009: Tegucigalpa.

[27] Berrios, F., SANAA multará a constructoras en Honduras, in El Heraldo. 2009: Tegucigalpa.

[28] SITRASANAAYS, SANAA, Una Experiencia Novedosa, ed. P.R. Rigoberto. 1998, Tegucigalpa: Guardabarranco, Editorial y Litografía.

[29] Barahona, L., En Sueño Profundo, Municipalización del Agua, in El Heraldo. 2009: Tegucigalpa.

[30] Strand, J., Water Pricing in Honduras: a Political Economy Analysis, in The Political Economy of Water Pricing Reforms, A. Dinar, Editor. 2000, Oxford University Press for the World Bank: Oxford. p. 405.

[31] Simon, H., D. Smithburg, and V. Thompson, Public Administration. 1991, New Jersey: Transaction Publishers. 582. 